\title{
Failure Analysis of Some Toyota Prius Battery Packs and Potential for Recovery
}

\author{
Peter Leijen and Jonathan Scott
}

\begin{abstract}
The Toyota Prius battery pack consists of 38 individual battery blades, each blade contains 6 NiMH cells in series. This means that each pack contains 228 NiMH cells. Each cell has the potential to fail. This report investigates the mode of failure of Prius battery packs by first analysing a number of packs in the lab, and then road testing them in a Toyota Prius. The analysis of the battery packs shows that some packs had aged "linearly", that is in a balanced manner, such that the state of health of all blades remained similar. However, in other packs discrete blades had significantly different states of health. A pack that consists of cells that are matched in both state of health and state of charge delivers the best performance. The research also showed that the worst cell in the pack determines the overall pack performance. This was demonstrated by substituting reducedcapacity or short-circuited blades into a functioning battery pack. A vehicle with a pack consisting of $372400 \mathrm{mAh}$ battery blades and one $1200 \mathrm{mAh}$ battery blade was only able to drive $1.3 \mathrm{~km}$ in Electric Vehicle mode, as opposed to $2.6 \mathrm{~km}$ with a pack consisting of $382400 \mathrm{mAh}$ battery blades.
\end{abstract}

\section{INTRODUCTION}

The Toyota Prius system is complex and contains a number of technically advanced systems that make diagnostics both interesting and difficult. The apparent ground loop though the converter assembly to the middle of the battery pack results in high voltages across the battery pack. The battery management ECU of the Toyota Prius measures various battery-related parameters including temperature, voltage and current. When one of these parameters falls outside of predetermined levels a diagnostic trouble code (DTC) is logged. The most common battery related DTCs are "leak detected" and "battery block malfunction".

The quality of the battery pack determines the fuel efficiency of the vehicle. Swings in battery voltage indicate to the battery management system when to start and stop charging with the internal combustion engine (ICE). Battery quality can be defined as its capacity or state of health [1]. There are many different methods of measuring state of health and state of charge as outlined in [1]-[6]. The easiest method of measuring blade capacity is Coulomb counting, a simple integral of current over time [7]. Battery state of health is more difficult to measure as we also need to take into account other failure methods such as short-circuited cells, etc. [8] One of us has outlined elsewhere the method used for measuring state of health and capacity in this report. [9]

The major concern to Prius owners is the lifetime of their battery pack. Toyota states that the battery pack will last $160,000 \mathrm{~km}$ or ten years. However Prius battery packs

Peter Leijen and Jonathan Scott are with the Department of Engineering, the University of Waikato, Hamilton, New Zealand. have failed prematurely. Failure can be caused by significant decrease in state of health of the entire pack or a decrease in state of health of an individual battery blade. This report will investigate the effects of a reduced-capacity blade, and the effects of a blade with very poor state of health, on the performance of the battery pack.

\section{TOYOTA PRIUS SySTEM}

The battery pack of the Toyota Prius consists of $38 \mathrm{NiMH}$ blades (Modules in figure 1) each of which contain six NiMH cells in series [10]. Toyota has designed their system to operate in a split battery fashion, i.e. the apparent 'ground' (chassis) of the HV battery pack occurs between blades 19 and 20, where the service plug is fitted. The battery management system of the Prius (figure 1) takes a differential voltage measurement across each pair of blades, the current into the pack is measured, and four temperature measurements are performed throughout the whole pack by the battery management ECU. Each pair of battery blades will be referred to as a battery block in this report.

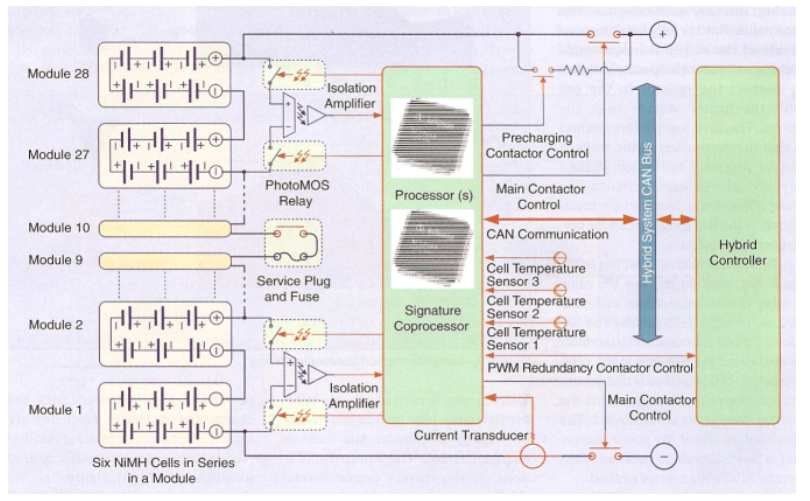

Fig. 1. Diagram of a typical Battery Management System for HEVs, for example the 2009 Toyota Prius. [11]

The diagram in figure 1 does not show how the inverter/converter assembly links the battery management ECU, the battery pack and the auxiliary power source ( $12 \mathrm{~V}$ battery). The inverter converts the DC battery voltage to a pseudo threephase sinusoidal waveform through 6 duty-cycle controlled switches (IGBTs). The three-phase voltage is used to drive the motor-generators and is the main source of propulsion. Belt-driven components such as the power steering pump, airconditioning compressor and the alternator have been removed from the ICE to further improve the fuel efficiency. The power steering hydraulics are driven by an electronic pump. Similarly 
the air-conditioning compressor has also been changed. The alternator has been replaced by a DC-DC converter.

\section{A. Converter}

The converter converts the high (300 V) DC voltage from the battery pack to 12 Volts (actually closer to $14.1 \mathrm{~V}$ ) to charge the auxiliary battery. The converter unit similar to the schematic shown in figure 2 contains a transformer isolated DC-DC converter. The primary side of the transformer is driven by the High Voltage (HV) battery through an $\mathrm{H}$ bridge creating a full-bridge converter. The full-bridge DC-DC converter design is suitable for high input voltages and high power output [12].

The output side of the converter consists of a centre-tapped secondary winding, two rectifier diodes, and an LC filter. The ground (chassis) of the vehicle is connected to the centre tap of the secondary coil. The negative terminal of the $12 \mathrm{~V}$ battery is also connected to the chassis of the vehicle as seen in most conventional vehicles. This is what causes the high impedance connection between vehicle chassis and the centre of the HV battery pack.

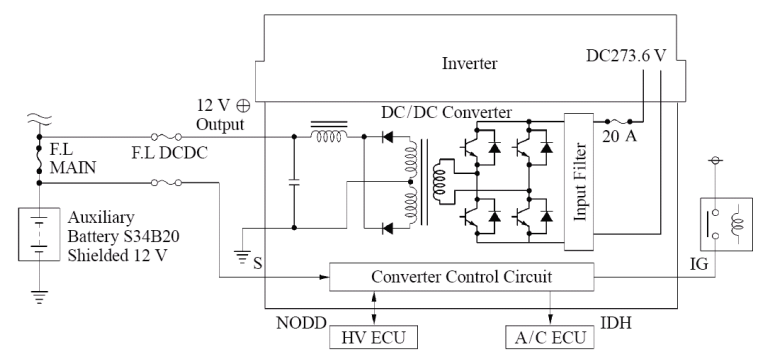

Fig. 2. Schematic of Toyota Prius converter unit [13].

The high impedance connection between chassis and the centre of the HV battery pack creates a ground loop, which leads to dangerous voltages even with the service plug removed as shown in figure 3 . The $12 \mathrm{~V}$ battery powers all the ECUs on board the Prius including the battery management ECU, which monitors the battery parameters.

\section{TOYOTA PRIUS BMS BATtery-RELATED FAUlT CODES}

The Toyota Prius battery management system (BMS) monitors battery temperature and battery voltage with the sensors explained in section II. If any of the voltages or temperatures of the battery blocks fall outside of predetermined trigger levels the BMS will log the malfunction and store a diagnostic trouble code (DTCs). The vehicle will then enter a so-called "turtle" mode when a code is set. Turtle mode is equivalent to limp-home mode in a conventional vehicle. In this state of operation the vehicle has reduced power output. For HEVs this means that the current drawn from the battery, and charging current, are limited resulting in poor fuel economy, and make the vehicle almost undrivable. Two of the most common battery-related DTCs are "Leak Detected" and "Battery Block Malfunction".

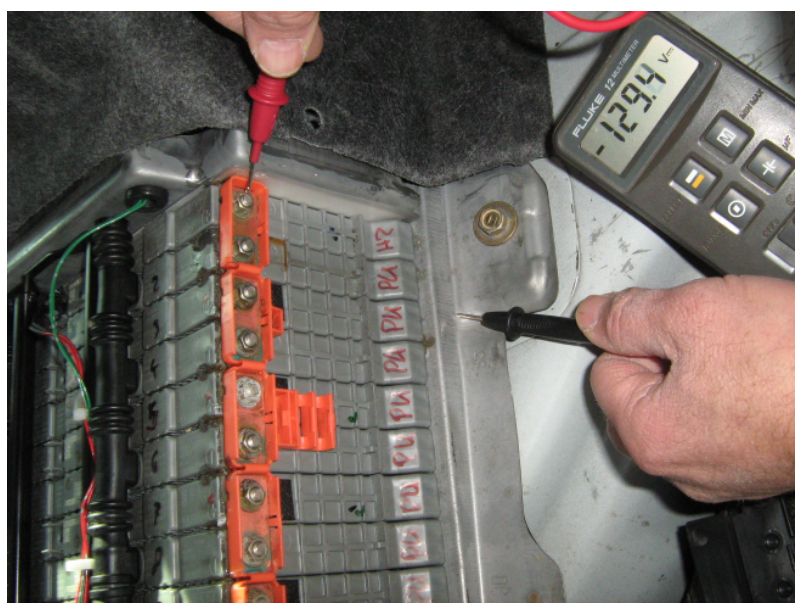

Fig. 3. Picture showing $-129.4 \mathrm{~V}$ measured between chassis and the Battery Pack with the service plug removed.

\section{A. Leak Detected}

Leak Detected (DTC P3009) occurs when the battery management ECU detects an electric leak in the high-voltage system. A leak such as this can seriously harm the human body [13]. The leak can be caused by damaged insulation on the HV cables, or a fault in the HV transaxle, converter, or inverter assemblies. There may also be other related DTCs present in the system [13].

One example we analysed showed an unusual cause for battery leakage. It was found that on some cells the seams had split leading to chemicals leaching out of the cell and conducting full or partial battery voltage to the outside of the cell, as shown in figure 4. If the leaking cell is touching the chassis it is possible for the battery voltage to be conducted to the chassis. Leakage can be caused by excessive pressures or temperatures within the battery blade.

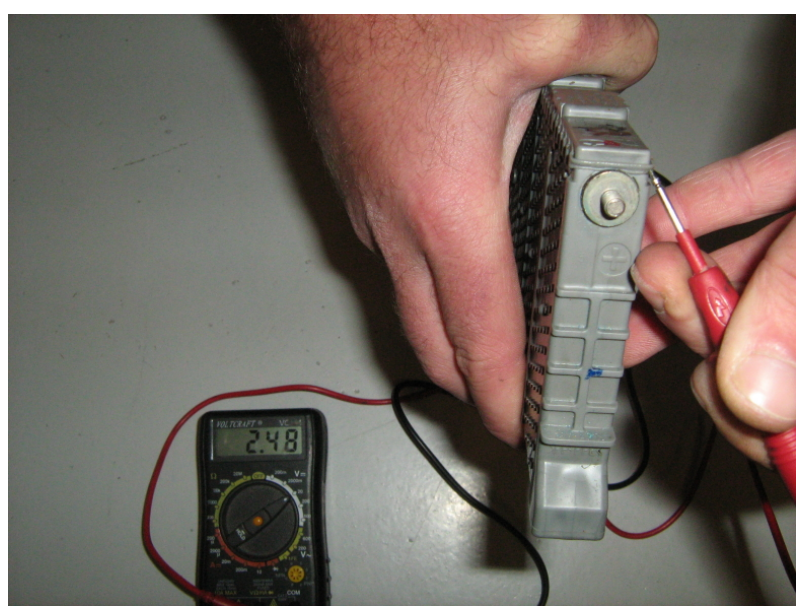

Fig. 4. Battery blade leakage.

Figure 4 shows $2.48 \mathrm{~V}$ being measured from the negative terminal of the battery blade to the seam around the positive terminal of the blade. This blade was removed from a vehicle which presented with the Leak Detected DTC. The blade was at one end of the battery pack so there was $18 \times 7.2+$ 
$2.4=132 \mathrm{~V}$ present across the chassis of the vehicle. If left untreated, the cells will eventually discharge due to the high impedance ground loop from chassis through the converter to the middle of the battery pack. This unmonitored discharge of cells within the battery pack leads to an imbalance in state of charge which causes the battery pack health to deteriorate at an increased rate. There have also been cases where the bottom of the cell has leaked and shorted to the chassis.

Insulating the cells from the chassis is a possible fix to this problem. The battery packs analysed during this research were fitted with a plastic layer between the side of the cell and the chassis, shown in figure 5. However this did not affect the cells that were leaking through the bottom.

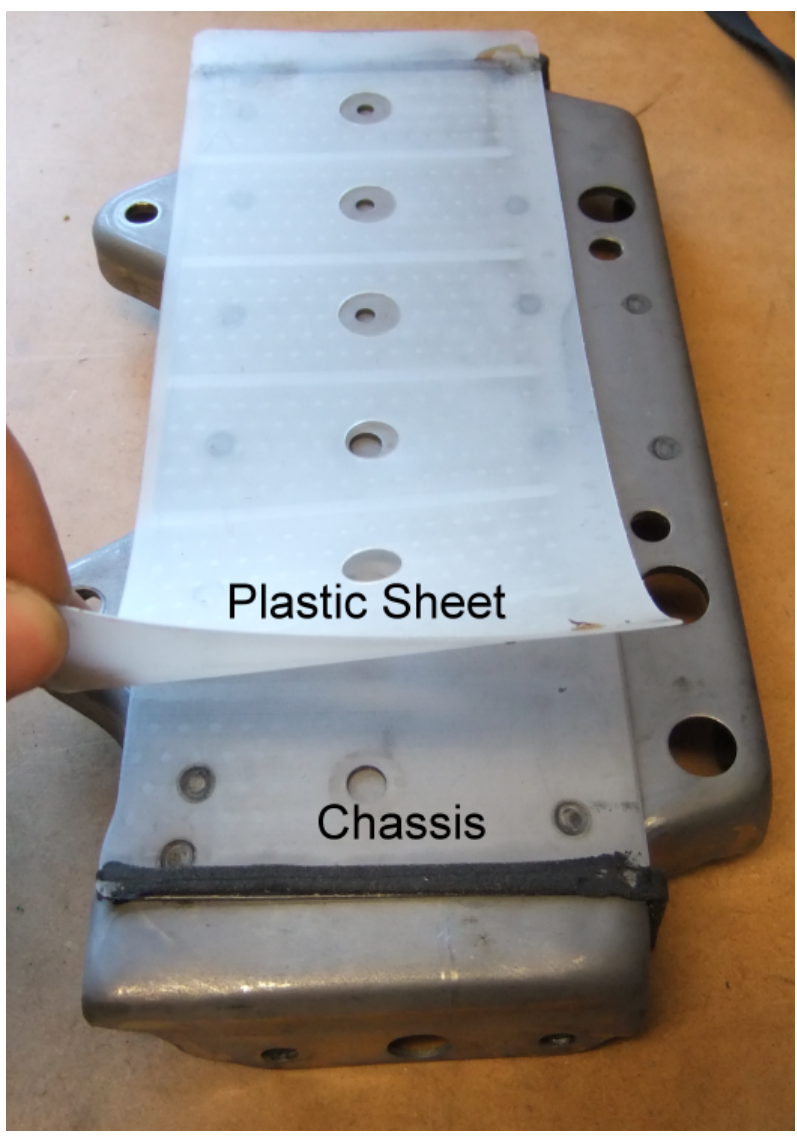

Fig. 5. Insulating plastic layer between battery blades and chassis.

\section{B. Battery Block Malfunction}

The Battery Block Malfunction DTC (DTC P3011 to P3029) is triggered by cells that have poor state of health. The battery management ECU looks at the voltage swing of individual battery blocks under charge and discharge. A voltage swing less than $0.3 \mathrm{~V}$ is acceptable (figure 6) according to Toyota repair advice [13]. This measurement technique is essentially a method for measuring the impedance of the battery block. Battery impedance is also related to the state of health of the cell [5], [6]. A cell with higher AC or DC impedance, higher voltage swing, is deemed to be of lesser state of health. This method also measures relative state of charge (SoC) between the battery blocks. The voltage of the block with less SoC will collapse before that of a cell with higher SoC.

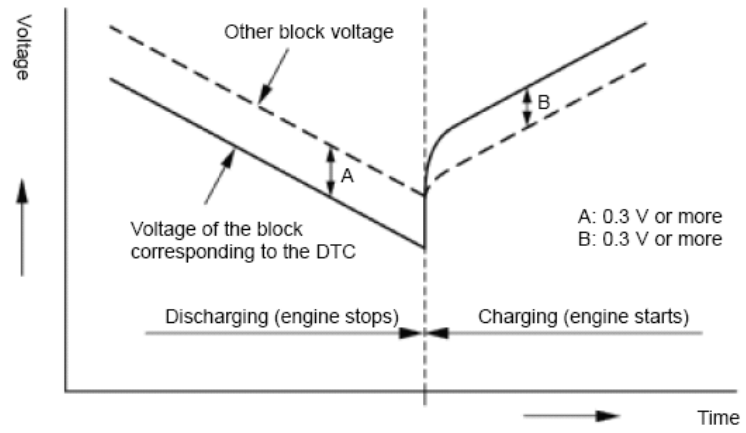

Fig. 6. Voltage difference while charging and discharging [13].

Another method of diagnosing this DTC, suggested by Toyota, is to look at the swing between the maximum and minimum block voltage, shown in figure 7 . The maximum allowable voltage swing is $2 \mathrm{~V}$.

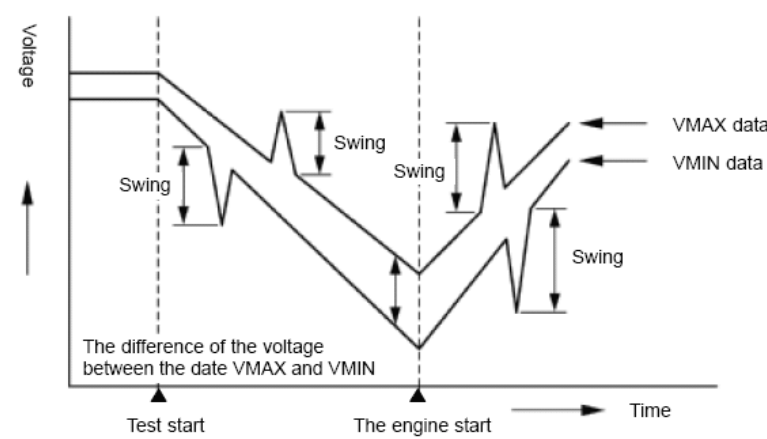

Fig. 7. Voltage difference while charging and discharging [13]

As mentioned above, this DTC is produced due to mismatching of battery blades within the battery pack. Replacing the complete battery pack assembly is one possible fix to this problem. This repair costs thousands of dollars which can be more than the car itself is worth.

\section{Testing Method}

The Battery Packs were analysed in the lab to find the capacity distribution and steady state voltages of the battery blades. Known broken and poor state of health cells were then substituted into a good battery pack and tested in the vehicle, a Toyota Prius (Model: NHW11, Engine Type: 1FX, Year: 2001), to investigate the failure methods of the battery packs. This gave both compatibility feedback, i.e. does the vehicle accept the battery pack, and performance results. The Prius was driven in EV mode (below $25 \mathrm{kmh}^{-1}$ ) and the distance travelled before the ICE switched on was measured. This gave an indication of the performance of the battery pack. The results were all compared to the original battery pack from the Prius which had done approximately $109,000 \mathrm{~km}$, and was considered healthy. 


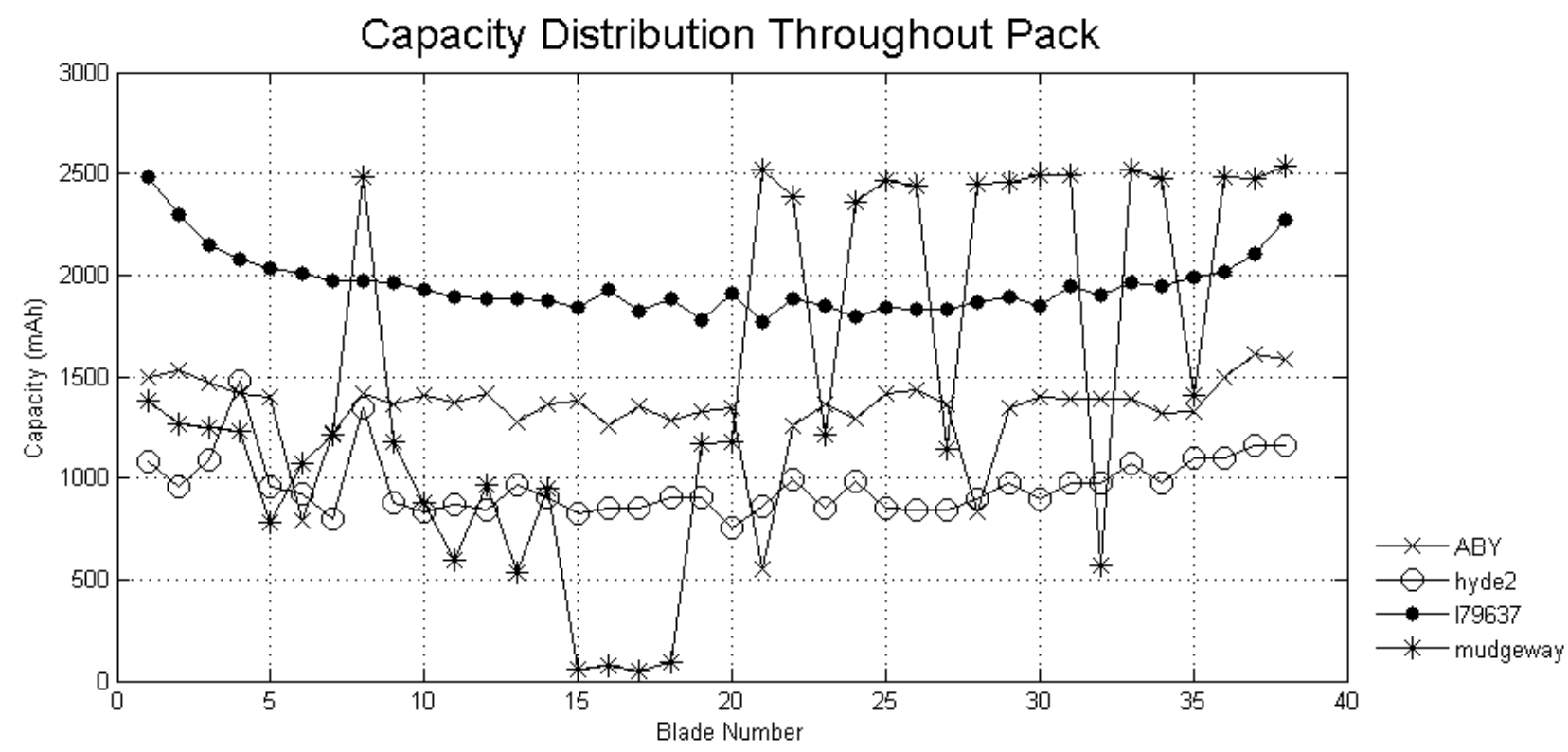

Fig. 8. Capacity Distribution throughout four packs tested.

Analysing the battery packs in the lab and road testing them gave an indication of why and how the packs deteriorate. Substituting broken and low capacity blades into a pack of good health will give an indication whether or not it is possible to build a pack of good health from a series of failed battery packs. The following sections look at the capacity distribution and steady-state voltages of a range of different Prius battery packs.

\section{CAPACITY Distribution}

Four different packs were tested; ABY, hyde2, I79637 and mudgeway. There was very little information available about hyde2 as it was recovered from a scrap metal dealer. Pack I79637 came out of a burnt-out Prius which had done approximately $69,649 \mathrm{~km}$. Pack mudgeway came from the local wreckers after having been on their yard for 14 months out in the open. Pack ABY was on loan from Toyota New Zealand and had done 74,697 km.

Figure 8 shows the measured capacities per battery blade, using the method described in [9]. Both packs hyde2 and I79637 have aged in a similar fashion i.e. the blades near the ends of the packs have higher capacities then the blades in the middle but are otherwise uniform. The "bathtub" curve capacity distribution may be caused by temperature differences throughout the pack during normal operation. Reading the live temperature data from the battery management ECU using a Launch X431 scantool revealed that the four temperature sensors show $31^{\circ} \mathrm{C}, 41^{\circ} \mathrm{C}, 43^{\circ} \mathrm{C}, 26^{\circ} \mathrm{C}$ respectively, indicating that blades in the centre of the pack can get up to $17^{\circ} \mathrm{C}$ warmer than blades on the outside of the pack during testing.

Pack I79637 was tested in the vehicle and performed the same as the original battery pack. The vehicle drove in EV mode for $2.6 \mathrm{~km}$. This suggests that the pack is in good health. The mudgeway pack threw the battery-block malfunction DTC and the vehicle went into "turtle" mode.

\section{A. Effect of one reduced capacity blade within a pack}

It was determined that pack I79637 was of good health because the pack performed the same as the original Prius battery pack. Cell \#38 (Cell ID 01M) from pack I79637 was replaced with cell \#38 (Cell ID 41D) from hyde2. The battery characteristics are summarised in table I. Cell 41D was chosen to have approximately half the capacity of rest of the pack with a similar steady state voltage.

\begin{tabular}{|c|c|c|}
\hline Cell ID & Capacity & Steady Voltage \\
\hline $01 \mathrm{M}$ & $2482.2 \mathrm{mAh}$ & $7.81 \mathrm{~V}$ \\
41D & $1164.4 \mathrm{mAh}$ & $7.55 \mathrm{~V}$ \\
\hline \multicolumn{3}{|c}{ TABLE I }
\end{tabular}

Cells replaced Within battery Pack.

Cell \#9 in the same pack was discharged to $6.2 \mathrm{~V}$ to investigate the effect, if any, of a discharged cell in the pack. The current through the pack, the overall voltage of the pack and the blade voltages of cell \#9, \#20, \#37 and \#38 were measured during driving. The scope trace of the measurements is shown in figure 9.

Figure 9 shows how the voltages of the four cells measured vary with current. The left hand cursor shows that when the cell is being charged (52.8 A positive current) the overall voltage of the pack is $355.1 \mathrm{~V}$. The voltage of cell \#38 is $9.39 \mathrm{~V}$ which is higher than cells \#37 and \#20 which are $9.16 \mathrm{~V}$ and $9.19 \mathrm{~V}$ respectively. Cell\#9, which was discharged before this test, is at $8.72 \mathrm{~V}$, significantly less than the other cells, and follows the voltage of cells \#37 and \#20 nicely.

At the end of heavy acceleration, identified by the right hand cursor in figure 9 , at a discharge of $63.4 \mathrm{~A}$, cell\#38 drops below cells \#37 and \#20 suggesting that this cell is reaching end-of-discharge voltage before any of the other cells. This has 


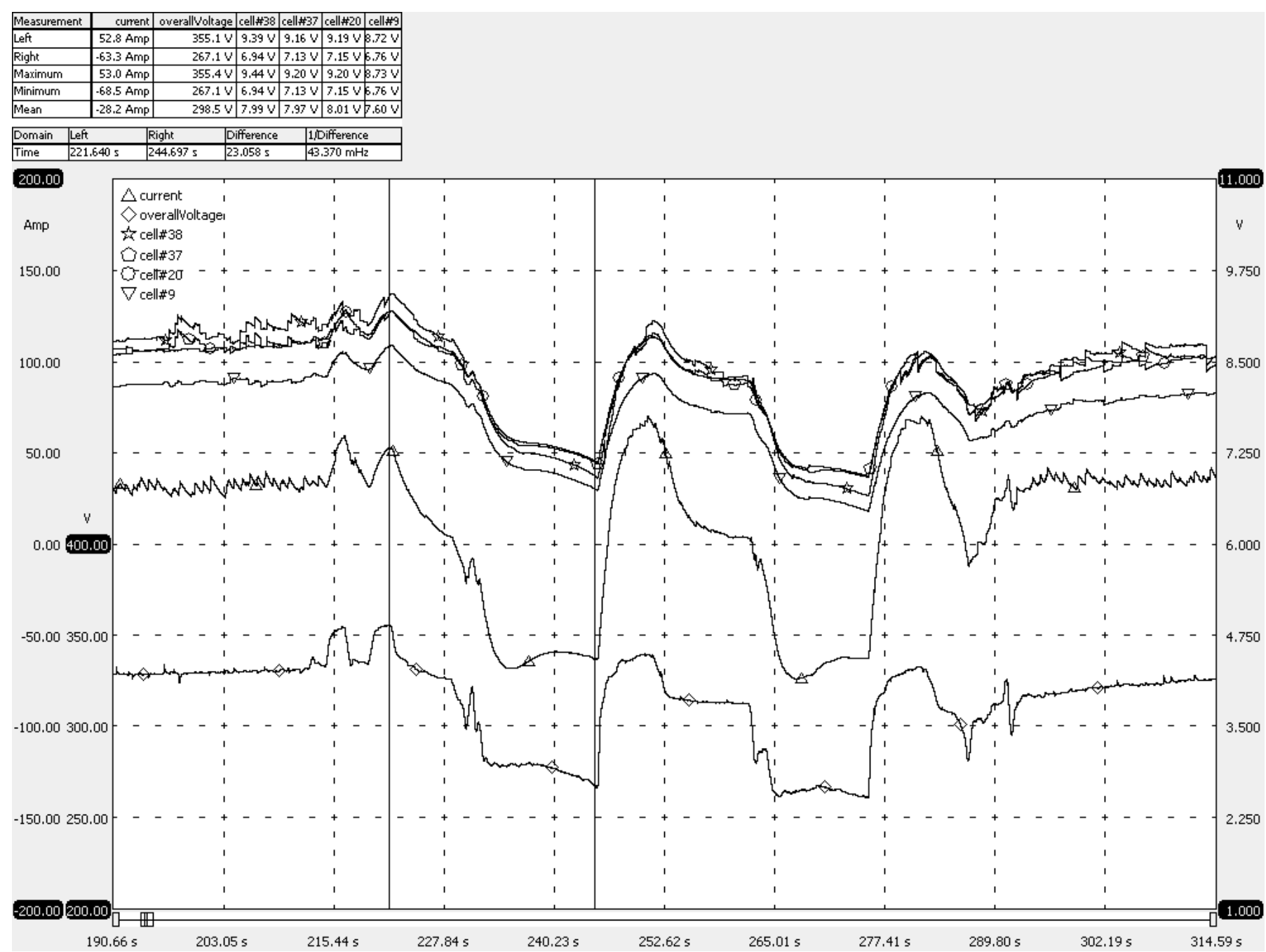

Fig. 9. Scope trace of current drawn from the battery pack, overall pack voltage and four blade voltages. The figure shows two full acceleration and hard brake cycles after a period of steady driving to boost the SoC of the pack to $62 \%$.

the effect that the vehicle starts charging again. This relates back to what is shown in figure 6 . The vehicle was only able to drive $1.3 \mathrm{~km}$ in EV mode with this pack configuration, half the distance of the original pack.

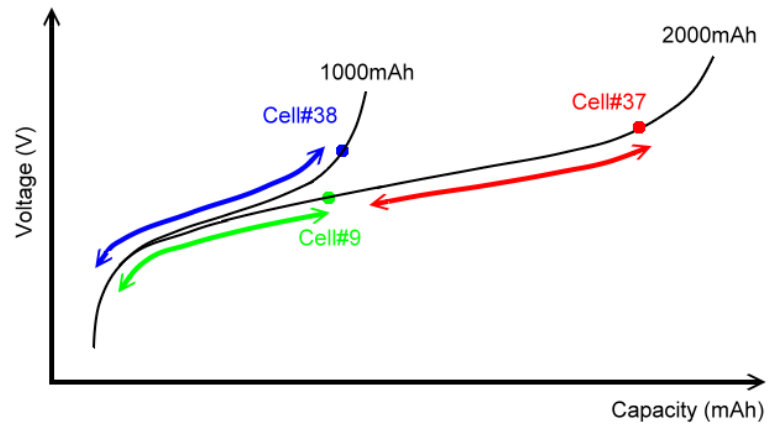

Fig. 10. Approximate relationship between the cells measured.

Figure 10 shows the approximate relationship between cells \#38, \#37 and \#9 drawn on their respective charge curves. The dot on the curves represents their starting positions, showing that both cells \#37 and \#38 were fully charged and cell \#9 was discharged before driving began. The double-headed arrows in figure 10 depict the voltage profile of the three cells. This figure does not take into account the hysteresis effect described by the Takacs model [14].

This test confirms that the battery pack is only as good as its weakest blade and that matching state of health and balancing state of charge in one battery pack is vital to the performance and fuel efficiency of the vehicle.

\section{Steady-State Voltage}

The steady-state voltage is the plateau voltage under discharge of the cell [9]. The results for the four packs tested are shown in figure 11. Steady-state voltage and capacity determine the state of health of the cell. If a cell's steadystate voltage is less than $7.2 \mathrm{~V}$, the nominal voltage of six NiMH cells in series [7], then this indicates that one cell is short-circuited, as depicted in figure 12. Battery blades that contain a broken cell usually have less capacity. 


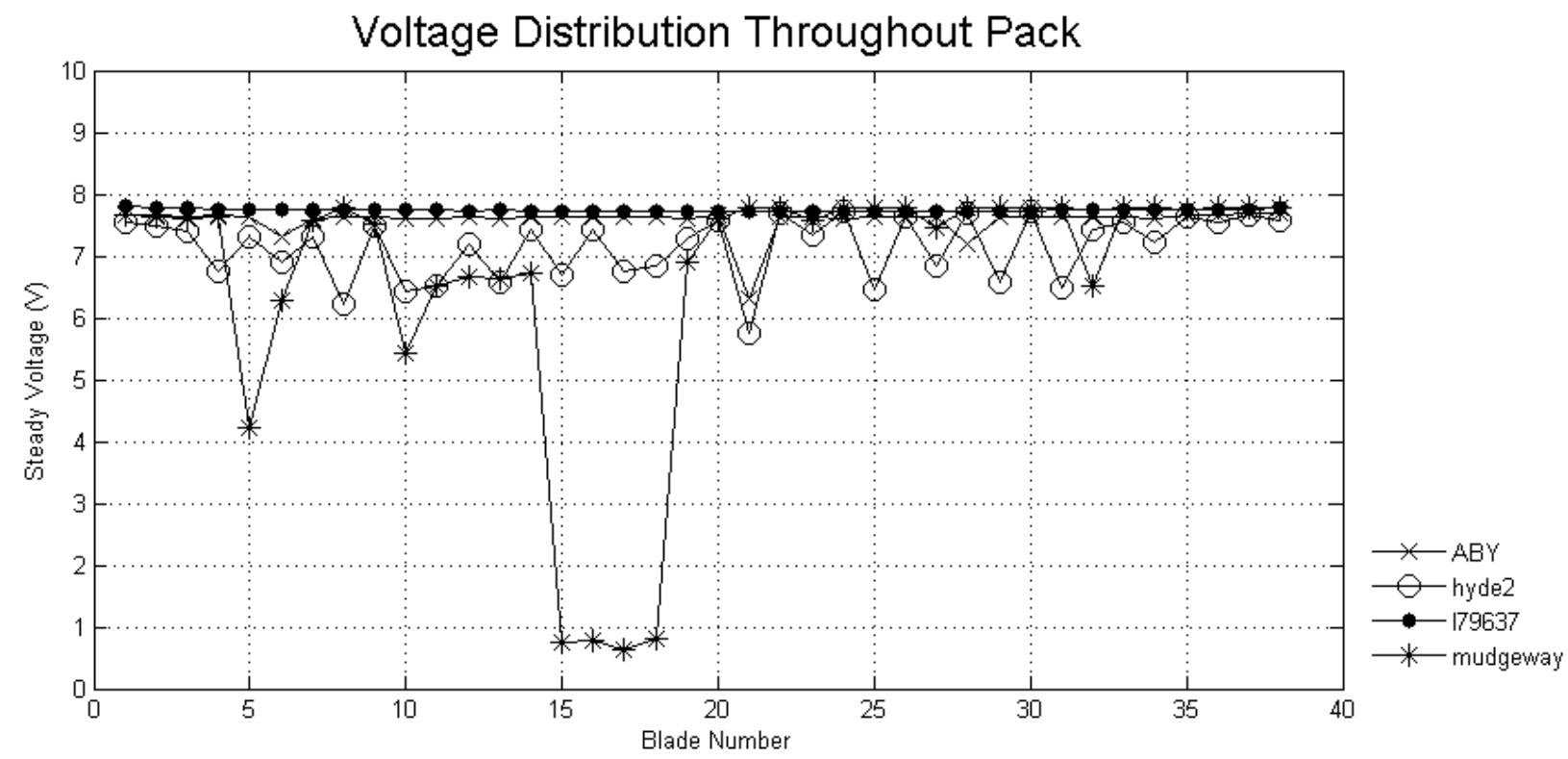

Fig. 11. Steady-state voltage distribution throughout the four packs tested. The steady-state voltage is the plateau of the discharge curve. The steady-state voltage is related to the health of the blade.

\section{ثНHНHHト}

Fig. 12. Broken battery blade steady-state voltage approximately $6.8 \mathrm{~V}$. The figure shows that the fourth cell in the blade is short-circuited.

\section{A. Effect of one broken blade within a pack}

Once again cell\#38 was taken out of pack 179637 and swapped for a different cell to investigate the effects. Cell\#38 was replaced by cell ID 72H. Data for both cells is summarised in table II.

\begin{tabular}{|c|c|c|}
\hline Cell ID & Capacity & Steady Voltage \\
\hline $01 \mathrm{M}$ & $2482.2 \mathrm{mAh}$ & $7.81 \mathrm{~V}$ \\
$72 \mathrm{H}$ & $963.3 \mathrm{mAh}$ & $6.67 \mathrm{~V}$ \\
\hline
\end{tabular}

TABLE II

CELLS REPLACED WITHIN BATTERY PACK.

The scope trace in figure 13 shows how the voltage of the broken cell (cell\#38) swings with respect to the other three cells measured. The voltage of cell\#38 reaches $10.62 \mathrm{~V}$ when charging at $61.9 \mathrm{~A}$ and drops to $3.81 \mathrm{~V}$ when drawing 18.9 A from the pack. This overcharge and over-discharge caused excessive pressure to build up in the blade and it was swollen when removed from the pack. The battery blade was analysed in the lab after vehicle testing and it was found that the capacity of the blade had reduced to $380 \mathrm{mAh}$.

The voltage swing of cell\#38, along with the lesser voltage swings of the other cells, causes the overall pack voltage to fluctuate by $56 \mathrm{~V}$. It is of no surprise then that the vehicle with this battery pack configuration was unable to drive 10 meters in EV mode. It is also no surprise that this battery pack configuration triggered a DTC. The two DTCs triggered were P3009: Battery levels are unusually different, and P3029: Battery block 19 becomes weak.

\section{CONCLUSION}

Many battery pack failures are caused by a single battery blade or block failing as shown in figure 8 and figure 11 . Figure 8 shows that the capacities of the blades within the pack either decrease in a linear and very consistent manner, exemplified by packs I79637 and hyde2, or the battery blade capacities decrease unpredictably as observed in the mudgeway and ABY battery packs. Pack I79637 is still of good health, indicated by its relatively high steady-state voltages. Pack hyde2 is of poor health, evidenced by both its low capacity and the number of blades with a steady-state voltage below 7.2 V. The capacities in the ABY pack have decreased linearly-only three blades have significantly less capacity and one battery blade has poor state of health. Figure 8 finally shows that failed battery packs contain good blades, in particular the blades from the mudgeway pack with capacities near $2500 \mathrm{mAh}$. These good blades could be matched in state of charge and state of health, and rebuilt into very usable second-hand battery packs. 


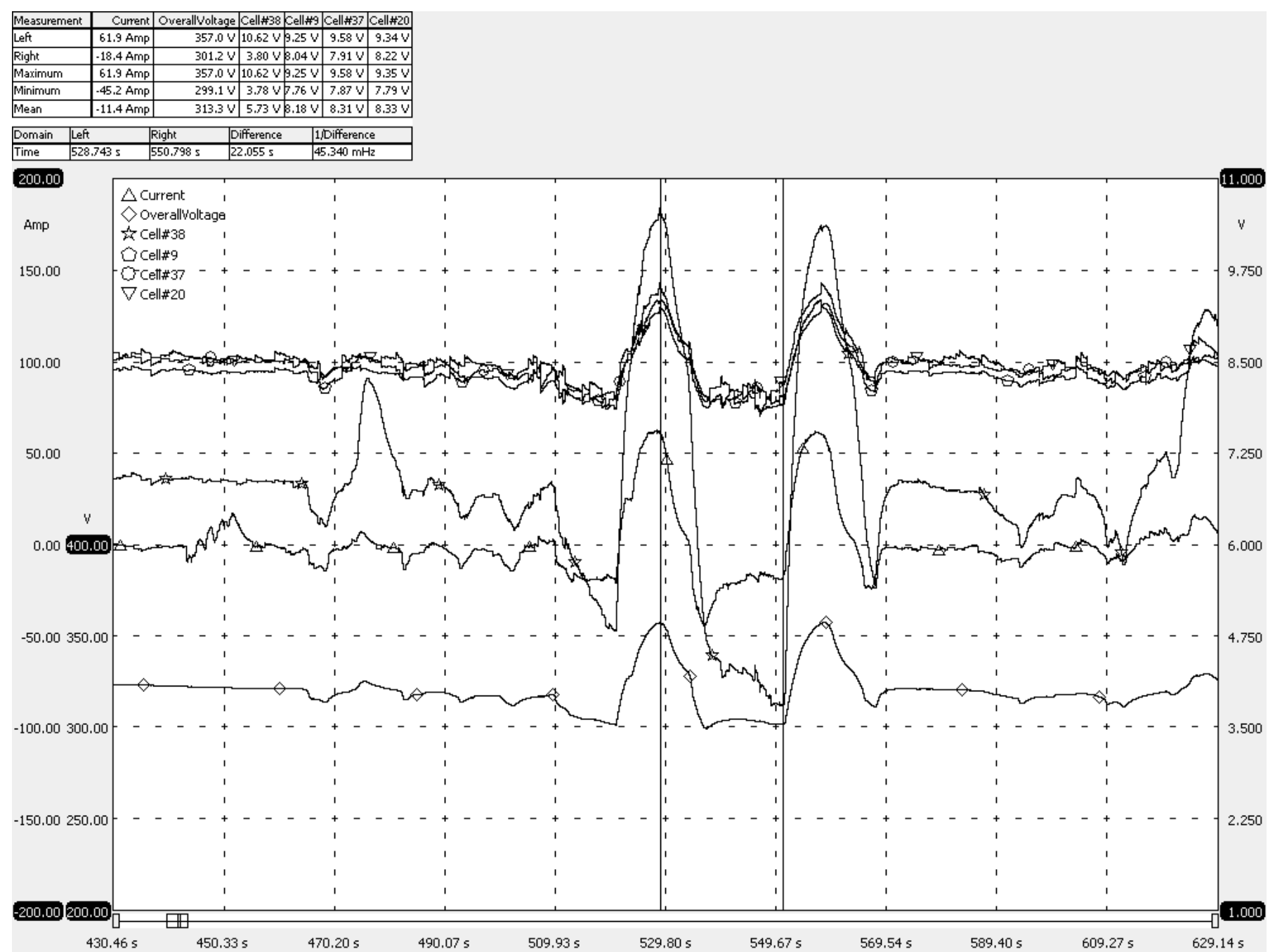

Fig. 13. Scope trace of current drawn from the battery pack, overall pack voltage and four blade voltages. The figure shows two hard acceleration and braking cycles after a period of steady driving to boost SoC of the pack to $62 \%$.

\section{ACKNOWLEDGEMENT}

We would like to thank Toyota New Zealand for providing Prius battery packs for analysis, Paul Hyde from Hyde Automotive for the battery packs he provided, and Mudgeway for their battery pack and associated parts which were used during the experiments. We would also like to thank AECS Ltd for providing valuable assistance with the interpretation of the test data and for the use of their test equipment.

\section{REFERENCES}

[1] G. L. Plett, "Recursive approximate weighted total least squares estimation of battery cell total capacity," Journal of Power Sources, vol. 196, no. 4, pp. 2319-2331, 2011.

[2] H. Li, C. Liao, and L. Wang, "Research on state-of-charge estimation of battery pack used on hybrid electric vehicle," IEEE, 2009, hard copy.

[3] W. Guoliang, L. Rengui, Z. Chunbo, and C. Chan, "State of charge estimation for nimh battery based on electromotive force method," IEEE Vehicle Power and Propulsion Conference, no. 3-5, 2008.

[4] K. Bundy, M. Karlsson, G. Lindbergh, and A. Lundqvist, "An electrochemical impedance spectroscopy method for prediction of the state of charge of a nickel-metal hydride battery at open circuit and during discharge," Journal of Power Sources, vol. 72, no. 2, pp. 118-125, 1998

[5] I. Buchmann, Batteries in a Portable World, second edition ed., C. E. Inc., Ed. Cadex Electronics Inc., 2001.
[6] L. Zhang, "Ac impedance studies on sealed nickel metal hydride batteries over cycle life in analog and digital operations," Electrochimica Acta, vol. 43, no. 21-22, pp. 3333-3342, 1998.

[7] P. Leijen, "Nimh state of charge and state of health measurement, and the prius battery system." 2011. [Online]. Available: www.pjmldesign.co.nz

[8] E. L. Schneider, W. Kindlein Jr, S. Souza, and C. F. Malfatti, "Assessment and reuse of secondary batteries cells," Journal of Power Sources, vol. 189, no. 2, pp. 1264-1269, 2009.

[9] P. Leijen, "Off-line nimh battery state of charge and state of health measurement," 2011. [Online]. Available: www.pjmldesign.co.nz

[10] W. K. Hu, M. M. Geng, X. P. Gao, T. Burchardt, Z. X. Gong, D. Norus, and N. K. Nakstad, "Effect of long-term overcharge and operated temperature on performance of rechargeable nimh cells," Journal of Power Sources, vol. 159, no. 2, pp. 1478-1483, 2006.

[11] J. Cao and A. Emadi, "Batteries need electronics," IEEE Industrial Electronics, vol. 5, no. 1, 2011.

[12] T. M. U. Ned Mohan and W. P. Robbins, Power Electronics Converters, Applications, and Design. John Wiley \& sons, inc., 1989.

[13] Toyota, Toyota Prius Workshop manual, 2001.

[14] N. A. Windarko, J. Choi, and Ieee, Hysteresis Modeling for Estimation of State-of-Charge in NiMH Battery Based on Improved Takacs Model, ser. International Telecommunications Energy Conference-INTELEC. New York: Ieee, 2009, pp. 598-603, iSI Document Delivery No.: BPG08 Times Cited: 0 Cited Reference Count: 11 Windarko, Novie Ayub Choi, Jaeho Proceedings Paper 31st International Telecommunications Energy Conference (INTELEC 09) Oct 18-22, 2009 Incheon, SOUTH KOREA 345 e 47th st, new york, ny 10017 usa. 